\title{
Profitabilitas Memoderasi Pengaruh Financial Distress pada Opini Audit Going Concern
}

\author{
Anak Agung Gde Oka Maheswara ${ }^{1}$ \\ Fakultas Ekonomi dan Bisnis Universitas \\ Udayana, Indonesia. \\ Email: \\ anakagunggdeokamaheswara@yahoo.com
}

\author{
A.A. Ngurah Bagus Dwirandra2 \\ Fakultas Ekonomi dan Bisnis \\ Universitas Udayana, Indonesia.
}

\begin{abstract}
ABSTRAK
Tujuan penelitian ini adalah untuk mengetahui pengaruh parsial financial distress pada opini audit going concern, untuk mengetahui pengaruh parsial profitabilitas pada opini audit going concern dan mengetahui kemampuan moderasi profitabilitas pada financial distress yang berpengaruh pada opini audit going concern. Penelitian ini dilakukan pada perusahaan manufaktur yang terdaftar di BEI pada tahun 2015-2017. Sampel penelitian diperoleh dengan menggunakan teknik purposive sampling. Pengumpulan data dilakukan dengan metode observasi non-partisipan. Teknik analisis data dilakukan dengan menggunakan metode analisis regresi logistik binary. Hasil pengujian menunjukkan bahwa financial distress berpengaruh pada opini audit going concern, profitabilitas tidak berpengaruh pada opini audit, dan profitabilitas melemahkan pengaruh financial distress pada opini audit going concern.
\end{abstract}

Kata Kunci : $\quad$ Financial Distress; Opini Audit Going Concern; Profitabilitas.

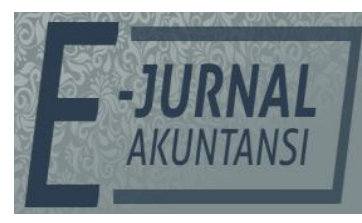

E-JA

e-Jurnal Akuntansi e-ISSN 2302-8556

Vol.298 No. 1 Denpasar, Oktober 2019

Hal. $420-436$

\section{Profitability Moderates the Effect of Financial Distress on Going Concern Audit Opinions}

Artikel masuk:

21 Mei 2019

\section{ABSTRACT}

The purpose of this study was to determine the effect of partial financial distress on the going concern audit opinion, to determine the effect of partial profitability on the going concern audit opinion and to know the moderating ability of profitability on financial distress that affects the going concern audit opinion. This research conducted at manufacturing companies listed on the Stock Exchange in 2015-2017. The research sample was obtained using purposive sampling technique. Data collection is done by non-participant observation methods. Data analysis techniques are carried out using the method of binary logistic regression analysis. The test results show that financial distress has an effect on the going concern audit opinion, profitability has no effect on the audit opinion, and profitability weakens the effect of financial distress on the going concern audit opinion.

Keywords: $\quad$ Financial Distress; Going Concern Audit Opinion; Profitability.

Tanggal diterima: 06 Juli 2019 


\section{PENDAHULUAN}

Opini audit going concern menurut Foster \& Jozep (2013) adalah opini audit yang diberikan auditor bila auditor menemukan berpandangan adanya keraguan mengenai kemampuan perusahaan. Menurut pandangan auditor, keputusan memberikan opini audit going concern tersebut melibatkan beberapa tahap analisis diantaranya menentukan adanya keraguan mengenai kemampuan perusahaan dalam melanjutkan bisnisnya, maka auditor dapat mengeluarkan laporan audit yang dimodifikasi untuk menggambarkan tentang masalah kelangsungan usaha perusahaan tersebut. Auditor memiliki tugas untuk memberikan opini atas kewajaran laporan keuangan perusahaan dan mengungkapkan permasalahan kelangsungan usaha (going concern) yang dihadapi perusahaan dalam mempertahankan kelangsungan usahanya.

Hao et al. (2011) menyatakan bahwa opini going concern memiliki dampak negatif yang signifikan terhadap nilai pasar klien dan bahkan dapat menarik perhatian regulator. Kepercayaan investor akan berkurang ketika auditor tidak memberikan unqualified opinion atau opini wajar tanpa pengecualian sehingga perusahaan akan mendesak auditor agar memberikan unqualified opinion atau opini wajar tanpa pengecualian. Kecermatan auditor dalam mempertimbangkan kelangsungan usaha sangat dibutuhkan, agar produk dari akuntan publik yaitu opini audit menjadi berkualitas.

Perkiraan pada perusahaan akan mengalami kebangkrutan dimasa mendatang dan keraguan terhadap kelangsungan hidup perusahaan juga merupakan pertimbangan bagi auditor dalam pengeluaran opini audit going concern. Kondisi kebangkrutan suatu perusahaan yang mengalami financial distress, yaitu adalah keadaan dimana kondisi keuangan perusahaan selama periode tertentu menghasilkan laba bersih (net profit) negatif selama beberapa tahun yang akhirnya akan mengarah ke kebangkrutan dan arus kas operasi perusahaan tidak mencukupi untuk melakukan tindakan perbaikan untuk mencegah terjadinya kebangkrutan (Piliang, 2018).

Kesulitan keuangan (financial distress) merupakan tahap penurunan kondisi keuangan yang dialami perusahaan dan terjadi sebelum terjadinya kebangkrutan atau likuidasi (Platt \& Platt, 2007). Kondisi ini dapat tercermin dari rasio keuangan yang dapat memberikan indikasi apakah perusahaan dalam kondisi baik (sehat) atau dalam kondisi bangkrut. Sehingga kondisi demikian ada beberapa faktor yang menyebabkan terjadinya opini audit going concern salah satunya adalah kesulitan keuangan suatu entitas. Menurut Wibisono (2011) menjelaskan bahwa financial distress adalah kesulitan keuangan yang dihadapi dalam mempertahankan keberlangsungan usaha di masa mendatang yang mungkin mengawali terjadinya kebangkrutan. Rahim (2016) menegaskan bahwa kesulitan keuangan yang dihadapi perusahaan inilah yang berpotensi diberikan opini audit going concern oleh auditor. Meskipun demikian ternyata tidak sedikit perusahaan yang go public memperoleh opini audit going concern.

Carcello \& Neal (2000) dalam Putra (2010) menyatakan bahwa semakin buruk kondisi keuangan perusahaan maka semakin besar kemungkinan perusahaan menerima opini audit going concern. Hal ini sejalan dengan penelitian Amyulianthy (2014) yang menyatakan bahwa adanya pengaruh positif antara financial distress yang diproksikan dengan Altman Z-Score pada penerbitan opini 
audit going concern. Namun, berbeda dengan penelitian oleh Ardiani et al. (2012), Amalia (2015), Doni \& Nazar (2015) dan Yuliyani (2017) yang menemukan bahwa tidak adanya pengaruh financial distress yang diukur dengan menggunakan model Altman Z-Score pada penerimaan opini audit going concern. Altman \& McGough (1974) dalam Werastuti (2013) mengatakan bahwa tingkat prediksi kebangkrutan dengan menggunakan model prediksi mencapai tingkat keakuratan $82 \%$ dibandingkan dengan menggunakan metode lain.

Purwanti \& Sumartono (2014) menyatakan bahwa financial distress akan menyebabkan perusahaan mengalami gangguan dalam keuangan seperti: arus kas negatif, rasio keuangan yang buruk, dan gagal bayar pada perjanjian utang. Kondisi keuangan perusahaan menggambarkan tingkat kesehatan perusahaan sesungguhnya. Pada perusahaan yang tidak sehat banyak ditemukan indikator masalah going concern. Santosa \& Wedari (2007) menyatakan bahwa semakin baik kondisi keuangan perusahaan semakin kecil kemungkinan bagi auditor untuk memberikan opini audit going concern, karena auditor hanya akan memberikan opini ini jika perusahaan dikatakan bangkrut atau sulit melanjutkan kelangsungan hidup usahanya. McKeown et al. (1991) dalam Husna (2014) berpendapat bahwa auditor mungkin saja gagal untuk memberikan pendapat tentang adanya indikasi kebangkrutan kepada suatu perusahaan yang ternyata mengalami kebangkrutan dalam beberapa tahun mendatang. Hal ini disebabkan karena perusahaan tersebut sedang berada dalam posisi ambang batas antara kebangkrutan dan kelangsungan usahanya.

Ross et al. (2002) menyatakan bahwa financial distress akan menyebabkan perusahaan mengalami gangguan dalam keuangan seperti: arus kas negatif, rasio keuangan yang buruk, dan gagal bayar pada perjanjian utang. Fanny \& Saputra (2005) dan Setyarno et al. (2006) menemukan bukti bahwa jika kondisi perusahaan dengan kondisi kinerja keuangan yang baik maka kemungkinan kecil perusahaan tersebut akan mendapat opini going concern dari auditor. Hasil penelitian ini sejalan dengan Rahim (2016) ketika suatu perusahaan mengalami permasalahan keuangan (financial distress), maka kegiatan operational perusahaan akan terganggu yang akhirnya dapat berdampak pada tingginya risiko yang dihadapi perusahaan dalam mempertahankan kelangsungan usahanya dimasa mendatang, menyebabkan berpengaruh pada opini audit yang akan diberikan oleh auditor. Hal ini bertentangan dengan penelitian Januarti (2009) dan Adriana et al. (2012) bahwa financial distress tidak memiliki pengaruh terhadap penerimaan opini audit going concern.

Berdasarkan paparan penelitian pengaruh financial distress tugas pada opini audit going concern ditemukan hasil yang variatif atau tidak konsisten atau masih kontroversi yang diduga karena adanya faktor lain yang mempengaruhi hubungan antara variabel bebas dengan variabel terikat. Govindarajan (1986) menyatakan bahwa kemungkinan belum adanya kesatuan hasil penelitian tergantung faktor-faktor tertentu atau lebih dikenal dengan istilah faktor kontinjensi. Murray (1990) menjelaskan bahwa agar dapat merekonsiliasi hasil yang saling bertentangan diperlukan pendekatan kontingensi untuk mengindentifikasi variabel lain yang bertindak sebagai pemoderasi ataupun pemediasi dalam model riset. Secara konseptual dan hasil riset empiris, terdapat beberapa variabel yang diduga berperan 
memoderasi pengaruh financial distress pada opini audit going concern, salah satu di antaranya patut dipertimbangkan yaitu profitabilitas.

Profitabilitas adalah kemampuan perusahaan memperoleh laba dalam hubungannya dengan penjualan, total aktiva, maupun modal sendiri (Sartono, 2001). Profitabilitas dapat diukur dengan rasio laba bersih sebelum pajak dibagi penjualan bersih (NIBTS). Semakin besar rasio ini menunjukkan kinerja perusahaan yang semakin baik untuk menghasilkan laba sehingga tidak menimbulkan keraguan auditor akan kemampuan perusahaan untuk melanjutkan usahanya dan dapat memperkecil kemungkinan penerimaan opini going concern. Penelitian, dan Chen \& B.K (1992), dan Behn et al. (2001) menemukan bahwa rasio ini berpengaruh negatif signifikan untuk memprediksi pembuatan keputusan opini going concern. Hal ini sejalan dengan penelitian Januarti \& Fitrianasari (2012), dan Widyantari (2011) menemukan bahwa profitabilitas tidak berpengaruh terhadap opini audit going concern. Namun penelitian Hani et al. (2003), Rahayu (2007), dan Setyarno et al. (2006) menemukan bahwa rasio profitabilitas tidak berpengaruh signifikan pada penerbitan opini audit going concern.

Profitabilitas menunjukkan keberhasilan perusahaan dalam menghasilkan laba, dengan demikian dapat dikatakan laba merupakan berita baik bagi perusahaan. Menurut Petronela (2007) profitabilitas merupakan kemampuan suatu perusahaan menghasilkan laba secara efektif dan efisien. Profitabilitas suatu perusahaan merupakan gambaran yang mengukur seberapa mampu perusahaan menghasilkan laba dari proses operasional yang telah dilaksanakan untuk menjamin kelangsungan perusahaan di masa yang akan datang. Nilai profitabilitas yang tinggi mengindikasikan kinerja manajemen yang relative baik dan hal tersebut memengaruhi semakin cepatnya manajemen melaporkan kinerjanya.

Proses pengauditan laporan keuangan akan semakin lama apabila perusahaan mengalami kerugian. Kartika (2011) menyatakan tingkat keuntungan digunakan sebagai salah satu cara untuk menilai keberhasilan efektivitas perusahaan. Lee \& Jahng (2008) menyatakan bahwa perusahaan yang mendapat laba akan mempermudah auditor di dalam proses pengauditan. Perusahaan yang memiliki tingkat profitabilitas yang lebih tinggi biasanya tidak memerlukan waktu yang lama di dalam melaporkan laporan keuangan auditan. Hal ini dikarenakan keharusan untuk menyampaikan kabar baik secepatnya kepada publik. Sedangkan, perusahaan yang memiliki profitabilitas rendah cenderung tidak tepat waktu dalam menyampaikan laporan keuangannya karena laporan keuangannya mengandung bad news. Perusahaan yang mengalami kerugian atau tingkat profitabilitasnya rendah akan membawa dampak buruk yang menyebabkan turunnya penilaian kinerja suatu perusahaan.

Adanya hubungan profitabilitas pada opini audit going concern menyebabkan profitabilitas diduga dapat memoderasi hubungan financial distress dalam memengaruhi opini audit going concern. Selama ini, penelitian mengenai opini audit going concern telah banyak dilakukan. Namun, pada kenyataannya penelitian mengenai opini audit going concern masih sangat penting untuk diteliti karena peneliti mencoba profitabilitas digunakan sebagai variabel moderasi 
untuk meneliti apakah dengan adanya profit perusahaan tetap bisa melangsungkan usahanya apabila terjadi kesulitan keuangan (financial distress).

Kesulitan keuangan (financial distress) merupakan suatu kondisi dimana perusahaan sedang menghadapi masalah kesulitan keuangan dapat diketahui dari ketidakmampuan perusahaan atau tidak tersedianya suatu dana untuk membayar kewajibannya yang telah jatuh tempo (Narayana, 2017). Penelitian oleh Amyulianthy (2014) dan Maryati (2015) yang menyatakan bahwa adanya pengaruh positif antara financial distress yang diproksikan dengan Altman Z-Score pada penerbitan opini audit going concern. Hal tersebut karena semakin rendah nilai Z-Score maka semakin besar kemungkinan perusahaan tersebut akan menerima opini audit going concern.

Perusahaan yang mengalami kondisi keuangan yang tidak sehat dikhawatirkan akan mengalami kebangkrutan kesulitan keuangan dimulai ketika perusahaan tidak dapat memenuhi jadwal pembayaran atau proyeksi arus kas mengindikasikan bahwa perusahaan tersebut akan segera tidak dapat memenuhi kewajibannya (Brigham, Eugene, \& Daves, 2004). Perusahaan yang mengalami financial distress ditandai dengan hilangnya pembayaran dividen atau adanya pemberhentian tenaga kerja, serta arus kas yang lebih kecil daripada hutang jangka panjang (Whitaker, 1999).

Dalam menjalankan tugasnya, manajemen seringkali dihadapkan pada kondisi perusahaan yang berpengaruh terhadap kelangsungan hidup perusahaan. Kelangsungan usaha yang terganggu menunjukkan keadaan keuangan yang buruk. Januarti (2009) menyatakan bahwa auditor tidak pernah memberikan opini audit going concern kepada perusahaan yang tidak pernah mengalami financial distress. Hal ini menunjukkan bahwa ketika perusahaan mengalami financial distress, maka perusahaan tersebut berpeluang mendapatkan opini audit going concern dari auditor karena perusahaan tersebut diragukan kelangsungan hidupnya dalam jangka waktu yang pendek maupun panjang.

Kondisi keuangan perusahaan yang terganggu menyebabkan perusahaan menerima opini audit going concern. Pendapat tersebut juga didukung oleh Setyarno et al. (2006) serta Rudyawan \& Badera (2009), dalam Siregar \& Rahman (2012) yang menyatakan bahwa, semakin baik kondisi keuangan perusahaan semakin kecil kemungkinan auditor memberikan opini audit going concern. Kondisi keuangan perusahaan merupakan kondisi yang dapat diukur secara kuantitatif untuk menggambarkan keadaan perusahaan. Kondisi keuangan perusahaan yang dimaksud adalah kondisi keuangan yang umumnya tergambar dalam laporan keuangan yang diterbitkan oleh perusahaan (Yati, 2011).

Kondisi financial distress yang dihadapi perusahaan merupakan signal bahwa perusahaan sedang menghadapi masalah keuangan, dan merupakan signal bagi auditor bahwa perusahaan sedang menghadapi masalah atau kondisi ketidakpastian yang dapat menimbulkan keraguan auditor atas kemampuan perusahaan dalam menjalankan usaha. Informasi bad news dapat berupa informasi mengenai penurunan kondisi keuangan perusahaan Luh et al. (2016), pendapat ini terkait dengan teori sinyal sebagai pemicu perusahaan mengalami financial distress yang akan diberikan opini audit going concern oleh auditor. Nariman (2017) teori sinyal mengajarkan bahwa setiap tindakan mengandung informasi. Teori sinyal dalam hal ini menekankan bahwa pentingnya informasi 
yang diberikan oleh auditor terhadap kondisi keuangan perusahaan. Apabila kondisi financial distress suatu perusahaan diketahui, maka informasi tersebut dapat membantu pihak agen menentukan keputusan dalam memperbaiki situasi perusahaan agar terhindar dari kebangkrutan. Hal Selanjutnya auditor akan memperhatikan informasi tersebut sebagai signal yang akan ditindaklanjuti untuk mengevaluasi rencana dan tindakan manajemen untuk mengatasi kesulitan keuangan tersebut.

Pada penelitian Ramadhany (2016), Praptitorini \& Januarti (2011), dan Putra (2010), yang meneliti tentang pengaruh model prediksi kebangkrutan Altman, terhadap opini audit going concern, yang hasilnya model prediksi kebangkrutan Altman berpengaruh signifikan yang positif terhadap opini audit going concern. Kondisi keuangan perusahaan menggambarkan tingkat kesehatan perusahaan. Carcello \& Neal (2000) menyatakan bahwa semakin buruk kondisi keuangan perusahaan maka semakin besar probabilitas perusahaan menerima opini going concern.

Berdasarkan uraian tersebut maka konseptual, kerangka pemikiran logis, hasil riset empiris dalam penelitian ini sebagai berikut :

$\mathrm{H}_{1}$ : Financial distress berpengaruh positif pada Opini Audit GoingConcern.

Profitabilitas adalah kemampuan perusahaan memperoleh laba tertarik dengan penjualan, total aktiva, maupun modal sendiri (Kristiana, 2012). Profitabilitas berkaitan dalam kemampuan perusahaan dalam mencapai keuntungan. Husnan (2001) menyatakan profitabilitas adalah kemampuan suatu perusahaan dalam menghasilkan suatu keuntungan (profit) pada tingkat penjualan, aset, dan modal saham tertentu. Menurut Petronela (2007) profitabilitas merupakan kemampuan suatu perusahaan dalam laba secara efektif dan efisien. Nilai profitabilitas yang tinggi mengidentifikasikan kinerja yang baik karena hal tersebut memengaruhi cepat atau lambatnya manajemen melaporkan kinerjanya.

Tujuan dari analisis profitabilitas adalah untuk mengukur tingkat efisiensi usaha dan profitabilitas yang dicapai perusahaan yang bersangkutan. Semakin tinggi rasio profitabilitas suatu perusahaan maka semakin baik kinerja perusahaan dalam menggelola aset-aset yang dimilikinya untuk mengasilkan profit. Sartono (2001) menjelaskan bahwa profitabilitas merupakan kemampuan perusahaan dalam memperoleh laba dalam hubungannya dengan penjualan, total aktiva, maupun modal sendiri. Rasio profitabilitas dapat diukur dengan menggunakan Return On Asset (ROA). Semakin tinggi nilai ROA, maka semakin baik prospek bisnisnya dan semakin efektif pula pengelola aktiva perusahaan sehingga auditor tidak meragukan kemampuan perusahaan untuk keberlangsungan usahanya.

Perusahaan dengan tingkat profitabilitas yang tinggi mengindikasikan bahwa perusahaan tersebut mampu menjalankan usahanya dengan baik sehingga dapat mempertahankan kelangsungan hidupnya. Dengan kata lain semakin tinggi tingkat profitabilitas maka semakin rendah pula kemungkinan pemberian opini going concern oleh auditor. Sebaliknya, perusahaan yang memiliki tingkat profitabilitas rendah maka cenderung akan mendapatkan opini going concern (Kristiana, 2012). 
Mutchler (1985), Chen \& B.K (1992), serta Behn et al. (2001), dan (Widyantari, 2011) mengemukakan bahwa rasio profitabilitas berpengaruh negatif signifikan untuk memprediksi pembuatan keputusan opini going concern. Hal ini sejalan dengan penelitian Hani et al. (2003), Rahayu (2007), Januarti \& Fitrianasari (2012) menemukan bahwa profitabilitas tidak berpengaruh signifikan terhadap opini audit going concern. Pemberian opini audit going concern mengindikasikan bahwa perusahaan berada dalam kondisi keuangan yang tidak baik yang ditandai dengan rasio profitabilitas yang rendah. Penelitian ini membuktikan bukti empiris bahwa profitabilitas yang rendah pun dapat memiliki opini audit un going concern.

Berdasarkan uraian tersebut maka konseptual, kerangka pemikiran logis, hasil riset empiris dalam penelitian ini sebagai berikut :

$\mathrm{H}_{2}$ : Profitabilitas berpengaruh negatif pada Opini Audit Going Concern.

Rasio Profitabilitas merupakan kemampuan suatu perusahaan menghasilkan laba secara efektif dan efisien, dimana rasio ini digunakan sebagai alat pengukur atas kemampuan perusahaan untuk memperoleh keuntungan dari setiap rupiah penjualan yang dihasilkan (Imam \& Evan, 2015). Profitabilitas menunjukkan keberhasilan perusahaan dalam menghasilkan laba. Profitabilitas adalah tingkat keberhasilan atau kegagalan perusahaan selama jangka waktu tertentu (Atmini, S., \& Wuryan, 2005). Hasil penelitian Arini (2010) menyatakan bahwa profitabilitas berpengaruh negatif dan signifikan terhadap kondisi financial distress perusahaan artinya semakin besar profitabilitas suatu perusahaan semakin mengurangi kondisi financial distress perusahaan tersebut dan rasio yang paling dominan dalam memprediksi kondisi financial distress adalah rasio profitabilitas dan memungkinkan perusahaan melangsungkan usahanya (going concern) karena kondisi financial distress tersebut dapat diperlemah dengan adanya profitabilitas.

Suatu kondisi dimana perusahaan sedang mengalami masalah kesulitan keuangan dapat diketahui dari ketidakmampuan perusahaan atau tidak tersedianya suatu dana untuk membayar kewajibannya yang telah jatuh tempo maka perusahaan tersebut dikatakan mengalami financial distress (Narayana, 2017). Perusahaan yang memiliki profitabilitas tinggi berarti memiliki laba yang besar. Ini berarti perusahaan tersebut semakin kecil kemungkinan untuk mengalami financial distress. Apabila sebuah perusahaan mengalami financial distress serta nilai profitabilitas yang dimiliki oleh perusahaan rendah, yang tercermin pada rendahnya keberhasilan perusahaan dalam menghasilkan laba, maka hal ini menjadi pertimbangan bagi auditor dalam menentukan opini audit going concern yang diberikan untuk perusahaan. Auditor akan menilai rendah kemampuan perusahaan mempertahankan kelangsungan usahanya dalam jangka panjangnya.

Gambaran tentang laba sudah digunakan secara luas sebagai satu indikator kinerja kunci dari suatu kegiatan komersial perusahaan dan hal ini juga menjadi sasaran utama dari manajemen. Kondisi perusahaan yang mengalami profit akan memungkinkan perusahaan menjalankan kelangsungan usahanya dikarenakan sebagai sinyal positif bagi para investor. Aplikasi teori prospek dalam kaitannya dengan kinerja perusahaan di pasar modal adalah adanya kepercayaan, tumpuhan, dan harapan investor tentang kinerja perusahaan yang 
berkaitan dengan laba perusahaan. Harapan-harapan ini akan mempunyai implikasi penilaian yang positif terhadap harga saham perusahaan (Skinner \& Sloan, 2000). Harapan inilah yang menjadi sinyal positif bagi para investor karena perusahaan akan tetap berjalan apabila perusahaan mengalami profit.

Dalam hal ini profitabilitas dapat memperlemah hubungan positif antara variabel financial distress pada opini audit going concern. Dengan bantuan nilai profitabilitas yang dimiliki perusahaan dapat membantu auditor dalam memberikan opini audit going concern.

Berdasarkan uraian tersebut maka konseptual, kerangka pemikiran logis, hasil riset empiris dalam penelitian ini sebagai berikut :

$\mathrm{H}_{3}$ : Profitabilitas melemahkan pengaruh positif Financial Distress pada Opini

Audit Going Concern

\section{METODE PENELITIAN}

Lokasi penelitian yaitu pada Bursa Efek Indonesia yang menyediakan data perusahaan-perusahaan go public yang telah diaudit tahun 2015-2017. Objek dalam penelitian ini adalah laporan keuangan perusahaan manufaktur yang sudah diaudit periode 2015-2017 di Bursa Efek Indonesia. Tahun penelitian 20152017 diambil karena keterbatasan waktu, tenaga dan biaya dari peneliti sehingga diambil periode penelitian selama 3 tahun.

Metode penentuan sampel yang digunakan adalah purposive sampling. Metode purposive sampling adalah metode pengumpulan sampel yang berdasarkan tujuan penelitian. Pengujian hipotesis dalam penelitian ini menggunakan analisis multivariate dengan menggunakan regresi logistik (logistics regretion), yang variabel bebas nya merupakan kombinasi antara metrik dan non metric (nominal). Model regresi dalam penelitian ini ditunjukkan dengan persamaan sebagai berikut:

$$
\begin{aligned}
& \operatorname{Ln} \frac{p(\text { OPINI })}{1-p(\text { OPINI })}=\alpha+\beta \mathrm{FD}+\varepsilon \\
& \operatorname{Ln} \frac{p(\text { OPINI })}{1-p(\text { OPINI })}=\alpha+\beta \text { FD }+\beta_{2} \text { Profit }+\beta_{3} \text { FD * Profit }+\varepsilon \\
& \mathrm{P}(\mathrm{OPINI}) \quad=\text { Opini Audit Going Concern } \\
& \alpha \quad=\text { Konstanta } \\
& \beta=\text { Koefisien regresi } \\
& \text { FD } \quad=\text { Financial Distress } \\
& \text { Profit = Profitabilitas } \\
& \text { FD * Profit } \quad=\text { Interaksi Financial Distress dan Profitabilitas } \\
& \varepsilon=\text { Residual error }
\end{aligned}
$$

\section{HASIL DAN PEMBAHASAN}

Analisis statistik deskriptif disajikan untuk memberikan informasi umum tentang karakteristik sampel yang berupa nilai tertinggi, nilai terendah, rata-rata, dan deviasi standar. Hasil statistik deskriptif dapat dilihat pada Tabel 1 sebagai berikut: 
Tabel 1. Hasil Statistik Deskriptif

\begin{tabular}{cccccc}
\hline Variabel & $\mathrm{N}$ & Minimum & Maximum & Mean & Std. Deviation \\
\hline $\begin{array}{c}\text { Financial } \\
\text { Distress }\end{array}$ & 210 & -10.00 & 21.65 & 2.1390 & 2.47073 \\
$\begin{array}{c}\text { Opini Audit } \\
\text { Going Concern }\end{array}$ & 210 & 0.00 & 1.00 & 0.0524 & 0.22333 \\
Profitabilitas & 210 & -302.35 & 105.22 & 6.4908 & 26.46704 \\
\hline
\end{tabular}

Sumber: Data Penelitian, 2019

Variabel financial distress dalam penelitian ini diukur menggunakan model Altman Z-Score. Model Altman (Z-Score) adalah model yang mengkaji pemanfaatan analisis rasio keuangan sebagai alat untuk memprediksi kebangkrutan. Berdasarkan Tabel 1, nilai rata-rata financial distress sebesar 2,139 bernilai positif, artinya rata-rata perusahaan yang diteliti tidak mengalami kesulitan keuangan dan tidak terancam bangkrut. Nilai standar deviasi atas financial distress sebesar 2,470 nilai ini lebih tinggi dibandingkan nilai rata-rata. Hal ini menunjukkan bahwa sebaran data financial distress tidak merata atau perbedaan data satu dengan data yang lainnya masih tergolong tinggi. Nilai minimum sebesar -10 dimiliki oleh perusahaan POLY pada tahun 2016, financial distress negatif dapat mengindikasikan bahwa perusahaan tersebut sedang mengalami kesulitan keuangan dan terancam bangkrut, sementara nilai maksimum sebesar 21,65 dimiliki oleh perusahaan DVLA pada tahun 2015, dapat dikatakan bahwa perusahaan tersebut memiliki kondisi keuangan yang baik, tidak sehingga mengalami kesulitan keuangan dan tidak terancam bangkrut.

Variabel profitabilitas dalam penelitian ini diukur menggunakan rasio return on asset (ROA). Berdasarkan Tabel 1, nilai rata-rata profitabilitas sebesar 6,4908 bernilai positif cenderung mendekati nilai maksimal, artinya rata-rata perusahaan yang diteliti memiliki kinerja yang baik dan mampu meningkatkan profitabilitas. Nilai standar deviasi atas profitabilitas sebesar 26,467 nilai ini lebih tinggi dibandingkan nilai rata-rata. Hal ini menunjukkan bahwa sebaran data profitabilitas tidak merata atau perbedaan data satu dengan data yang lainnya masih tergolong tinggi. Nilai minimum adalah sebesar $-302,35$ dimiliki oleh perusahaan IKAI pada tahun 2017, profitabilitas negatif dapat mengindikasikan bahwa perusahaan memiliki kualitas dan kinerja fundamental yang menurun, sementara nilai maksimum sebesar 105,22 dimiliki oleh perusahaan DVLA pada tahun 2015, dapat dikatakan bahwa perusahaan tersebut sudah mampu meningkatkan kualitas dan kinerja fundamentalnya, sehingga dapat mencapai profitabilitas yang maksimal.

Variabel opini audit going concern dalam penelitian ini diukur menggunakan variabel dummy yaitu opini audit going concern diberi kode 1 dan opini non-going concern diberi kode 0 . Nilai standar deviasi atas opini audit going concern sebesar 0,22333 nilai ini lebih tinggi dibandingkan nilai rata-rata 0,0524. Hal ini menunjukkan bahwa sebaran data opini audit going concern tidak merata atau perbedaan data satu dengan data yang lainnya tergolong tinggi. Hal ini disebabkan karena sebagian besar perusahaan yang di teliti memiliki opini nongoing concern dan hanya sebagian kecil yang memiliki opini going concern. Secara lebih rinci frekuensi perusahaan yang memperoleh opini going concern dapat dilihat pada Tabel 2 berikut: 
Tabel 2. Frekuensi Opini Going Concern

\begin{tabular}{llrrrr}
\hline & Frequency & Percent & Valid Percent & $\begin{array}{c}\text { Cumulative } \\
\text { Percent }\end{array}$ \\
\hline Valid & opini non going & 199 & 94.8 & 94.8 & 94.8 \\
& $\begin{array}{l}\text { concern } \\
\text { opini going concern }\end{array}$ & 11 & 5.2 & 5.2 & 100.0 \\
& 210 & 100.0 & 100.0 & \\
\hline
\end{tabular}

Sumber: Data Penelitian, 2019

Data pada Tabel 2 menunjukkan jumlah perusahaan yang memperoleh opini non-going concern sebanyak 199 perusahaan dan yang memperoleh opini going concern sebanyak 11 perusahaan. Hal ini menunjukkan terdapat perbedaan yang cukup tinggi antara perusahaan yang memperoleh opini non-going concern dibandingkan perusahaan yang memperoleh opini going concern.

Model regresi yang baik adalah tidak terjadi korelasi diantara variabel bebas. Untuk mendeteksi ada atau tidaknya korelasi antar variabel bebas dapat dilihat dari nilai tolerance dan nilai variance inflation factor (VIF). Jika nilai tolerance lebih dari 10\% atau VIF Kurang dari 10, maka dapat dikatakan model telah bebas dari multikolinearitas.

Tabel 3. Hasil Uji Multikolinearitas

\begin{tabular}{cccc}
\hline Variabel & Tolerance & VIF & Keterangan \\
\hline financial distress & 0,691 & 1,447 & $\begin{array}{c}\text { Bebas } \\
\text { multikolinearitas } \\
\text { Bebas }\end{array}$ \\
profitabilitas & 0,556 & 1,798 & $\begin{array}{c}\text { multikolinearitas } \\
\text { Bebas } \\
\text { multikolinearitas }\end{array}$ \\
\hline
\end{tabular}

Sumber: Data Penelitian, 2019

Berdasarkan Tabel diatas dapat dilihat bahwa nilai tolerance dan VIF dari seluruh variable tersebut menunjukkan bahwa nilai tolerance untuk setiap variabel lebih besar dari 10\% dan nilai VIF lebih kecil dari 10 yang berarti model persamaan regresi bebas dari multikolinearitas.

Untuk menilai Keseluruhan Model (Overal Model Fit) pada analisis regresi logistik dapat dilakukan dengan cara menilai angka -2 log likelihood. Apabila terjadi penurunan angka -2 log likelihood dari awal (blok number $=0$ ) pada angka -2 log likelihood pada blok number $=1$, maka menunjukkan model regresi yang baik.

Tabel 4. Overal Model Fit

\begin{tabular}{cccccc}
\hline \multicolumn{3}{c}{$2 \log$ likelihood } \\
\hline \multirow{3}{*}{ Step } & 1 & blok number $=0$ & & \multicolumn{2}{c}{ blok number $=1$} \\
0 & 2 & 104.211 & Step 1 & 1 & 89.757 \\
& 3 & 87.851 & & 2 & 59.255 \\
& 4 & 86.325 & 3 & 51.319 \\
& 5 & 86.296 & 4 & 49.473 \\
& 6 & 86.296 & 5 & 49.309 \\
& & 86.296 & 6 & 49.307 \\
\hline
\end{tabular}

Sumber: Data Penelitian, 2019 
Hasil uji Keseluruhan Model (Overal Model Fit) pada Tabel diatas menunjukkan bahwa angka -2 log likelihood pada awal (blok number $=0$ ) dan -2 log likelihood pada blok number $=1$ mengalami penurunan, hal ini menunjukkan model regresi yang baik.

Dasar pengambilan keputusan menggunakan nilai godness of fit test yang diukur dengan nilai chis square pada bagian bawah uji Hosmer dan Lemeshow. Apabila probabilitas $>0,05$ maka Ho diterima dan Ha ditolak, sebaliknya apabila probabilitas < 0,05 maka Ho ditolak dan Ha diterima. Hasil uji Hosmer dan Lemeshow dapat dilihat pada Tabel berikut:

Tabel 5. Hasil Uji Hosmer dan Lemeshow

\begin{tabular}{lllll}
\hline Step & Chi-square & df & \multicolumn{2}{c}{ Sig. } \\
\hline 1 & 10.946 & & 8 & 0.093 \\
\hline
\end{tabular}

Sumber: Data Penelitian, 2019

Nilai Chi Square tabel untuk DF 8 pada taraf signifikansi 0,05 adalah sebesar 14,067. Karena nilai Chi Square Hosmer and Lemeshow hitung 10,946 < Chi Square table 14,067 atau nilai signifikansi sebesar 0,093 lebih besar dari 0,05, sehingga menerima H0, yang menunjukkan bahwa model dapat diterima dan pengujian hipotesis dapat dilakukan sebab ada perbedaan yang tidak signifikan antara model dengan nilai observasinya.

Besarnya nilai koefisien determinasi ditunjukkan dengan nilai Nagelkerke $R$ Square pada model regeresi logistic. Nilai Nagelkerke's $R$ Square adalah variabilitas variabel tetap yang dapat dijelaskan oleh variabel bebas, sedangkan sisanya dijelaskan oleh variabel-variabel lain di luar penelitian. Nagelkerke's $R$ Square ini digunakan untuk mengukur seberapa besar variabel bebas yang digunakan dalam penelitian ini yaitu financial distress mampu mempengaruhi variabel terikat opini audit going concern. Hasil uji Nagelkerke $R$ Square dalam penelitian ini dapat dilihat pada Tabel berikut ini :

Tabel 6. Hasil Uji Nagelkerke R Square

\begin{tabular}{lrrr}
\hline Step & -2 Log likelihood & Cox \& Snell R Square & Nagelkerke R Square \\
\hline 1 & $49.307^{a}$ & 0.161 & 0.479 \\
\hline
\end{tabular}

Sumber: Data Penelitian, 2019

Hasil uji pada Tabel 6 memberikan hasil dimana diperoleh nilai Nagelkerke $R$ Square adalah sebesar 0,479. Ini berarti variasi opini going concern pada perusahaan manufaktur yang terdaftar di Bursa Efek Indonesia periode 20152017 dapat dipengaruhi secara signifikan oleh variabel financial distress sebesar 47,9 persen, sedangkan sisanya sebesar 52,1 persen dijelaskan oleh faktor-faktor lain yang tidak dijelaskan dalam model penelitian.

Regresi logistik uji Wald digunakan menguji ada tidaknya pengaruh dari variabel terikat secara parsial dengan cara membandingkan nilai statistik Wald dengan nilai pembanding Chi square pada derajat bebas $(\mathrm{db})=1$ pada alpha $5 \%$ atau dengan membandingkan nilai signifikansi ( $p$-value) dengan alpha sebesar $5 \%$ dimana p-value yang lebih kecil dari alpha menunjukkan bahwa hipotesis diterima atau terdapat pengaruh yang signifikan dari variabel bebas terhadap variabel terikat secara parsial. Hasil uji hipotesis dapat dilihat pada Tabel 7 berikut: 
Tabel 7. Hasil Uji Wald

\begin{tabular}{|c|c|c|c|c|c|c|c|}
\hline & & B & S.E. & Wald & $\mathrm{df}$ & Sig. & $\operatorname{Exp}(B)$ \\
\hline \multirow[t]{2}{*}{ Step $1^{\mathrm{a}}$} & LnX & 2.291 & 0.632 & 13.133 & 1 & 0.000 & 9.883 \\
\hline & Constant & -3.983 & 0.549 & 52.668 & 1 & 0.000 & 0.019 \\
\hline
\end{tabular}

Sumber: Data Penelitian, 2019

Berdasarkan hasil analisis pengaruh financial distress terhadap opini going concern diperoleh nilai signifikasi uji wald sebesar 0,000 dengan nilai koefisien Wald positif sebesar 2,291. Nilai Signifikansi 0,000 < 0,050 mengindikasikan bahwa $\mathrm{H}_{0}$ ditolak dan $\mathrm{H}_{1}$ diterima. Hasil ini mempunyai arti bahwa financial distress berpengaruh positif dan signifikan terhadap opini going concern pada perusahaan manufaktur yang terdaftar di Bursa Efek Indonesia periode 20152017.

Untuk mengetahui apakah variabel profitabilitas mampu memoderasi pengaruh variabel financial distress terhadap Opini audit going concern, maka digunakan model pengujian interaksi (Moderated Regression Analysis-MRA). Model ini bertujuan untuk mengetahui apakah variabel moderasi mampu mempengaruhi hubungan antara variabel bebas dan variabel terikat, dimana dalam persamaan regresinya mengandung unsur interaksi. Hasil analisis uji interaksi dengan menggunakan program SPSS dapat dilihat pada Tabel 8.

Tabel 8. Hasil Uji Moderated Regression Analysis

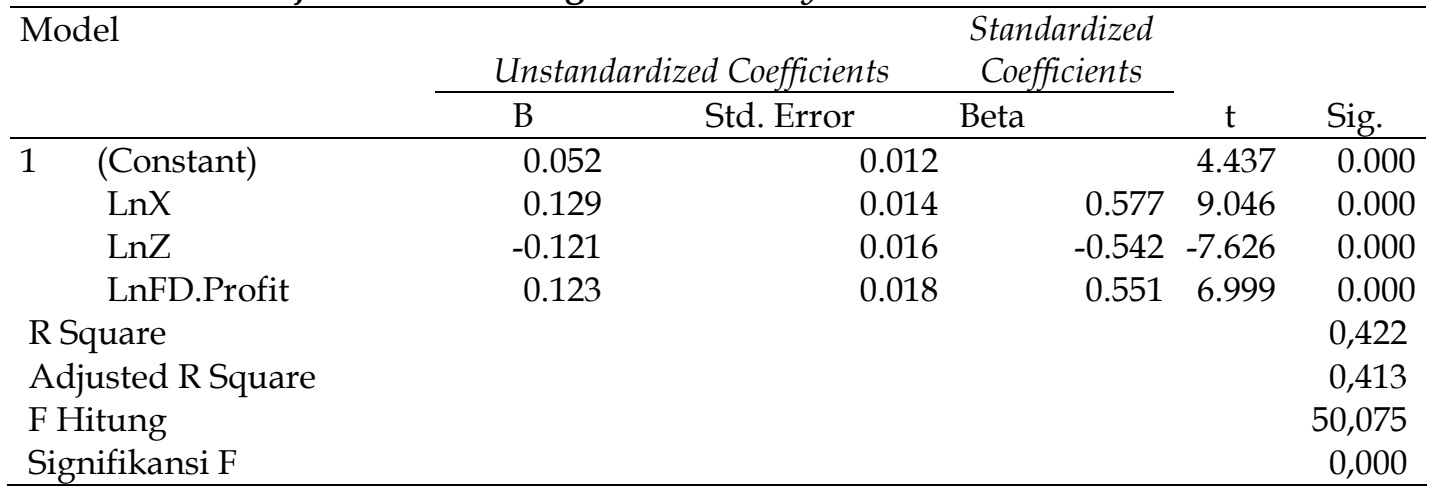

Sumber: Data Penelitian, 2019

Berdasarkan hasil analisis regresi moderasi seperti yang disajikan pada

Tabel 8, maka persamaan strukturalnya adalah sebagai berikut :

$$
\begin{gathered}
\mathrm{Ln}=\alpha+\beta \text { FD }+\beta_{2} \text { Profit }+\beta_{3} \text { FD * Profit }+\varepsilon \\
L n=0,052+0,129 \text { FD }-0,121 \text { Profit }+0,123 \text { FD * Profit }+\varepsilon
\end{gathered}
$$

Pemilihan model persamaan ini didasarkan pada penggunaan model logaritma natural (Ln) yang memiliki keuntungan, yaitu untuk menyamakan satuan dan meminimalkan kemungkinan terjadinya heterokedastisitas karena transformasi yang menempatkan skala untuk pengukuran variabel, dan koefisien kemiringan $\beta i$ langsung dapat menunjukkan elastisitas $Y$ terhadap $X i$ yaitu persentase perubahan dalam $\mathrm{Y}$ akibat adanya persentase perubahan dalam $\mathrm{Xi}$ (Gujarati, 2003).

Hasil uji koefisien determinasi dalam Tabel 6 menunjukkan besarnya nilai adjusted $\mathrm{R}^{2}$ adalah sebesar 0,413 . Ini berarti variasi opini audit going concern dapat dipengaruhi secara signifikan oleh variabel financial distress, profitabilitas, dan variabel interaksi antara financial distress dengan profitabilitas sebesar 41,3 persen sedangkan sisanya sebesar 58,7 persen dijelaskan oleh faktor-faktor lain. 
Hasil uji $\mathrm{F}$ (Ftest) menunjukkan bahwa nilai signifikansi $\mathrm{P}$ value 0,000 yang lebih kecil dari $a=0,05$, ini berarti model yang digunakan pada penelitian ini adalah layak. Hasil ini memberikan makna bahwa seluruh variabel independen yaitu financial distress, profitabilitas, dan variabel interaksi antara financial distress dengan profitabilitas mampu memprediksi atau menjelaskan fenomena opini audit going concern pada seluruh sampel perusahaan manufaktur yang terdaftar di Bursa Efek Indonesia tahun 2015-2017. Hal ini berarti model dapat digunakan untuk analisa lebih lanjut atau dengan kata lain model dapat digunakan untuk memproyeksikan karena hasil goodness of fitnya baik dengan nilai signifikansi P value 0,000.

Berdasarkan hasil uji analisis regresi moderasi, pada Tabel 8 dapat diketahui bahwa pengaruh financial distress terhadap opini audit going concern $\left(b_{1}\right)$ diperoleh nilai signifikansi sebesar 0,000 (significant) dengan nilai koefisien regresi positif sebesar 0,129 . Nilai signifikansi variabel moderasi profitabilitas pada opini audit going concern $\left(\mathrm{b}_{2}\right)$ sebesar 0,000 (significant) dengan nilai koefisien regresi negatif sebesar $-0,121$ dan nilai koefisien regresi variabel interaksi antara profitabilitas dengan financial distress pada opini audit going concern $\left(b_{3}\right)$ sebesar 0,123 dengan signifikan sebesar 0,000, hal ini mengindikasikan variabel moderasi merupakan tipe moderasi semu (quasi moderasi), karena koefisien $\mathrm{b}_{2}$ significant dan koefisien $\mathrm{b}_{3}$ significant. Quasi moderasi merupakan variabel yang memoderasi hubungan antara variabel prediktor dan variabel tergantung di mana variabel moderasi semu berinteraksi dengan variabel prediktor sekaligus menjadi variabel prediktor (Solimun, 2010:33).

Hasil analisis regresi moderasi pada Tabel 8 menunjukkan bahwa nilai koefisien regresi financial distress $\left(\beta_{1}\right)$ positif signifikan dan variabel interaksi antara financial distress dengan profitabilitas $\left(\beta_{3}\right)$ negatif signifikan, yang menunjukkan arah koefisien berlawanan, maka dapat disimpulkan bahwa variabel profitabilitas $\left(\mathrm{X}_{2}\right)$ merupakan variabel moderasi yang memperlemah pengaruh financial distress pada opini audit going concern.

\section{SIMPULAN}

Kesimpulannya adalah Financial distress yang diproksikan dengan model prediksi kebangkrutan Altman Z Score secara statistik berpengaruh signifikan dengan penerimaan opini audit going concern dengan nilai koefisien regresi positif sebesar 0,129 dengan signifikansi 0,000 $(<0,05)$. Jadi dapat disimpulkan bahwa financial distress perusahaan berpengaruh positif signifikan terhadap penerimaan opini audit going concern dan hipotesis penelitian dapat diterima. Profitabilitas berpengaruh negatif pada opini audit going concern. Hal ini menunjukkan bahwa semakin besar nilai rasio profitabilitas suatu perusahaan maka semakin besar kemampuan perusahaan tersebut untuk menghasilkan laba sehingga tidak menimbulkan keraguan auditor akan kemampuan perusahaan untuk melanjutkan usahanya. Hasil penelitian ini konsisten dengan hasil penelitian (Mutchler, 1985), (Chen \& B.K, 1992), (Behn Bruce et al., 2001) yang menunjukkan bahwa profitabilitas berpengaruh negative signifikan untuk memprediksi pembuatan keputusan opini going concern. Variabel profitabilitas merupakan variabel moderasi yang dapat memperlemah hubungan antara 
financial distress pada opini audit going concern. Yang artinya perusahaan tetap bisa melangsungkan usahanya dimasa yang akan datang apabila perusahaan mendapatkan profit walaupun terjadi financial distress.

Penelitian selanjutnya diharapkan menambahkan variabel-variabel lain yang dianggap mempengaruhi opini audit going concern baik itu rasio keuangan dan faktor non keuangan yaitu arus kas, ukuran perusahaan, pertumbuhan perusahaan, debt default.

Bagi investor, agar memperhatikan dengan teliti bagaimana perusahanperusahan yang terdaftar di BEI tersebut apakah dalam kondisi kesulitan keuangan atau dalam kondisi memperoleh laba hal ini diperlukan untuk meminimalisir terjadinya kerugian investasi.

Bagi auditor, mempertimbangkan faktor-faktor apa saja yang bisa memperlemah hubungan antara financial distress pada opini audit going concern selain profitabilitas agar perusahaan tetap bisa melangsungkan usaha seterusnya.

Bagi manajemen perusahaan, agar usaha yang lebih giat dalam memperoleh laba untuk perusahaan guna mengurangi perusahaan mengalami kesulitan keuangan demi melangsungkan usahanya dalam jangka panjang dan seterusnya.

\section{REFERENSI}

Adriana, Azwir, N., \& Rusli. (2012). Analisis Prediksi Kebangkrutan Menggunakan Metode Springate pada Perusahaan Foods And Beverages Yang Terdaftar di Bursa Efek Indonesia Periode 2006-2010. Skripsi.

Altman, E., \& McGough, T. (1974). Evaluation of A Company as A Going Concern. Journal of Accountancy, 50-57.

Amalia, R. F. (2015). Pengaruh Opini Audit, Pergantian Manajemen, Audit Fee Terhadap Auditor Switching Secara Voluntary dengan Reputasi Auditor sebagai Variabel Moderating (Studi Kasus: Perusahaan Manufaktur pada Sub Sektor Industri Dasar dan Kimia yang Terdaftar di BEI Tahun . Jurnal Ekonomi Dan Bisnis, 5.

Amyulianthy, R. (2014). Faktor Determinan Opini Audit Going Concern. Liquidity, 3(1), 27-35. https:/ / doi.org/10.32546/lq.v3i1.102

Ardiani, N., Emrinaldi, N. D., \& Nur, A. (2012). Pengaruh Audit Tenure, Disclosure, Ukuran KAP, Debt Default, Opinion Shopping, Dan Kondisi Keuangan terhadap Penerimaan Opini Audit Going Concern Pada Perusahaan Real Estate Dan Property Di Bursa Efek Indonesia. Jurnal Ekonomi, 20, 32.

Arini, D. (2010). Analisis Rasio Keuangan Untuk Memprediksi Kondisi Financial Distress Perusahaan Manufaktur Yang Terdaftar Di Bursa Efek Jakarta. Thesis.

Atmini, S., \& Wuryan, A. (2005). Manfaat Laba Dan Arus Kas untuk Memprediksi Kondisi Financial Distress Pada Perusahaan Textile Mill Products Dan Apparel And Other Textile Products yang Terdaftar di Bursa Efek Jakarta. SNA VIII Solo, (September), 460-474.

Behn Bruce, K., Steven, K., \& Kip, K. (2001). Further Evidence on the Auditor's Going-Concern Report: The Influence of Management Plans. Auditing: A Journal of Practice $\mathcal{E}$ Theory, 20, 13-18. 
Brigham, Eugene, F., \& Daves, P. R. (2004). Intermediate financial management. In The British Accounting Review (Vol. 21). https://doi.org/10.1016/08908389(89)90100-5

Chen, K. C. ., \& B.K, C. (1992). Default on Debt Obligation and the Issuance of Going-Concern Report. Auditing: A Journal of Practice $\mathcal{E}$ Theory, 30-49.

Doni, I. B., \& Nazar, M. R. (2015). Pengaruh Likuiditas, Nilai Tukar Valuta Asing, Reputasi KAP, Debt Default Dan Financialdistress Terhadap Penerimaan Opini Audit Modifikasi Going Concern (Studi Kajian Pada Perusahaan Pertambangan Yang Terdaftar Pada Bursa Efek Indonesia Periode 20102013). E-Proceeding of Management, 2(1), 389-401.

Fanny, M., \& Saputra, S. (2005). Opini Audit Going Concern : Kajian Berdasarkan Model Prediksi Kebangkrutan, Pertumbuhan Perusahaan, Dan Reputasi Kantor Akuntan Publik (Studi Pada Emiten Bursa Efek Jakarta). Simposium Nasional Akuntansi VII Solo, 966-978.

Foster, P. ., \& Jozep, Z. (2013). Loan Defaults And Hazard Models For Bankruptcy Prediction. Managerial Auditing Journal, 6.

Govindarajan, V. (1986). Impact of Participation in The Budgetary Process on Managerial Attitudes and Performance. Decision Sciences, 496-516.

Gujarati, D. (2003). Ekonometri Dasar. Terjemahan: Sumarno Zain. Jakarta: Erlangga.

Hani, Clearly, \& Mukhlasin. (2003). Going-Concern dan Opini Audit: Suatu Studi Pada Perusahaan Perbankan di BEJ. Simposium Nasional Akuntansi VI. Surabaya: 16-17 Oktober.

Hao, Q., Zhang, X., Wang, Y., Yang, C., \& Zhao, G. (2011). Audit Quality and Independence in China: Evidence From Going-Concern Qualifications Issued During 2004-2007. International Journal of Business, Humanities and Technology, 1(2), 111-119.

Husna, A. (2014). Pengaruh Debt Default dan Financial Distress Terhadap Opini Audit Going Concern. Skripsi, 57.

Husnan, S. (2001). Manajemen Keuangan Teori Dan Penerapan (Keputusan Jangka Pendek).

Imam, M., \& Evan, M. S. (2015). Analisis rasio keuangan untuk memprediksi kondisi financial distress perusahaan manufaktur yang terdaftar di bursa efek indonesia. Jurnal Akuntansi Universitas Jember, 139-154.

Januarti, I. (2009). Analisis Pengaruh Faktor Perusahaan, Kualitas Auditor dan Kepemilikan Perusahaan Terhadap Penerimaan Opini Audit Going Concern (Perusahaan Manufaktur Yang Terdaftar di Bursa Efek Indonesia). Diponegoro Journal of Accounting, 1-26.

Januarti, I., \& Fitrianasari, E. (2012). Analisis Rasio Keuangan dan Rasio Non Keuangan yang Mempengaruhi Auditor Dalam memberikan Opini Audit Going Concern pada Auditee (Studi Empiris pada Perusahaan Manufaktur yang Terdaftar di BEJ tahun 2000-2005). MAKSI.

JV Carcello, \& TL Neal. (2000). Audit Committee Composition and Auditor Reporting. The Accounting Review, 75(4), 453-467.

Kartika, A. (2011). Faktor-faktor yang mempengaruhi audit delay pada perusahaan manufaktur yang terdaftar di BEI. Dinamika Keuangan Dan Perbankan, 3(2), 152-171.

Kristiana, I. (2012). Pengaruh Ukuran Perusahaan, Profitabilitas, Likuiditas, 
Pertumbuhan Perusahaan Terhadap Opini Audit Going Concern Pada Perusahaan Manufaktur Yang Terdaftar di Bursa Efek Indonesia. Berkala Ilmiah Mahasiswa Akuntansi, 1.

Lee, H. Y., \& Jahng, G. (2008). Determinants Of Audit Report Lag: Evidence From Korea - An Examination. The Journal of Applied Business Research, 24(June 2008), 27-44. https:/ / doi.org/10.19030/jabr.v24i2.1352

Luh, N., Merta, K., Asri, I. G. A. M., \& Putri, D. (2016). Kemampuan Profitabilitas Memoderasi Pengaruh Likuiditas dan Leverage Terhadap Financial Distress. E-Jurnal Ekonomi Dan Bisnis, 10, 3419-3448.

Maryati, S. (2015). Faktor-faktor yang Mempengaruhi Kecenderungan Penerimaan Opini Audit Going Concern pada Perusahaan Manufaktur Yang Terdaftar di Bursa Efek Indonesia Periode Tahun 2010-2013. Skripsi, 13(3), 1576-1580.

McKeown, J. R., Jane, F. M., \& Hopwood, W. (1991). Towards an Explanation of Auditor Failure to Modify the Audit Opinions of Bankrupt Companies. A Journal of Practice and Theory, 1-13.

Murray, D. (1990). The Performance Effects of Participative Budgeting, an Interpretation of Intervening and Moderating Variables. Behavioral Research in Accounting, 2, 104-123.

Mutchler, J. (1985). A Multivariate Analysis of the Auditor's Going Concern Opinion Decision. Journal of Accounting Research, 23, 668-682.

Narayana, D. G. A. (2017). Pengaruh Struktur Kepemilikan , Financial Distress dan Audit Tenure pada Ketepatwaktuan Publikasi Laporan Keuangan. EJurnal Akuntansi Universitas Udayana, 18, 2085-2114.

Nariman, A. (2017). Pengaruh Ukuran Kantor Akuntan Publik Terhadap Opini Going Concern Dan Earnings Response Coefficients (Erc) Pada Perusahaan Manufaktur Yang Terdaftar Di Bei Tahun 2011-2013. Jurnal Akuntansi, 19(2), 160. https://doi.org/10.24912/ja.v19i2.92

Petronela, T. (2007). Analisis Skala Perusahaan, Opini Audit, dan Umur Perusahaan atas Audit Delay. Akuntabilitas, 6.

Piliang, E. (2018). Mengelola Perubahan Lingkungan Bisnis : Analisis Model Altman' S Z-Score. (March), 33-50.

Platt, H. D., \& Platt, M. B. (2007). Predicting corporate financial distress: Reflections on choice-based sample bias. Journal of Economics and Finance, 26(2), 184-199. https:// doi.org/10.1007/bf02755985

Praptitorini, M. D., \& Januarti, I. (2011). Analisis Pengaruh Kualitas Audit, Debt Default Dan Opinion Shopping Terhadap Penerimaan Opini Going Concern. Jurnal Akuntansi Dan Keuangan Indonesia, 8(1), 78-93. https://doi.org/10.21002/jaki.2011.05

Purwanti, M., \& Sumartono. (2014). Pengaruh Kompetensi Dan Independensi Auditor Terhadap Efektifitas Proses Audit Serta Dampaknya Pada Ketepatan Pemberian Opini Akuntan Publik. Study \& Accounting Research, 21(1), 33-51.

Putra, I. G. C. (2010). Opini Audit Going Concern: Kajian Berdasarkan Prediksi Kebangkrutan dan Auditor Independen. Universitas Udayana.

Rahayu, P. (2007). Assesing Going Concern Opinion: A Study Based on Financial and Non-Financial Information. Jurnal Dan Prosiding Simposium Nasional 
Akuntansi X, 10.

Rahim, S. (2016). Pengaruh Kondisi Keuangan Perusahaan, Kualitas Audit dan Opinion Shopping Terhadap Penerimaan Opini Going Concern. Jurnal $\begin{array}{llll}\text { Ilmiah Akuntansi Dan } & \end{array}$ https://doi.org/10.24843/jiab.2016.v11.i02.p02

Ramadhany, A. (2016). Analisa Faktor-Faktor Yang Mempengaruhi Penerimaan Opini Going Concern Pada Perusahaan Manufaktur Yang Mengalami Financial Distress di Bursa Efek Jakarta. Jurnal Wira Ekonomi Mikroskil, Vol. 6, pp. 85-101.

Ross, S. a, Westerfield, \& Jaffe. (2002). Corporate Finance, Sixth Edition. McGraw-Hill Primis, 1, 972.

Rudyawan, A. P., \& Badera, I. D. N. (2009). Opini Audit Going Concern: Kajian Berdasarkan Model Prediksi Kebangkrutan, Pertumbuhan Perusahaan, Leverage, dan Reputasi Auditor. Jurnal Ilmiah Akuntansi Dan Bisnis, 4(2), 117.

Santosa, A. F., \& Wedari, L. K. (2007). Analisis Faktor-faktor yang Mempengaruhi Kecenderungan Penerimaan Opini Audit Going Concern. JAAI, 11, 141-158.

Sartono, A. (2001). Manajemen Keuangan. Universitas Gadjah Mada.

Setyarno, E. B., Januarti, I., \& Faisal. (2006). Pengaruh Kualitas Audit, Kondisi Keuangan Perusahaan, Opini Audit Tahun Sebelumnya, Pertumbuhan Perusahaan Terhadap Opini Audit Going Concern. Simposium Nasional Akuntansi IX Padang, 1-25.

Siregar, B., \& Rahman, A. (2012). Faktor-faktor yang mempengaruhi kecenderungan penerimaan opini audit going concern pada perusahaan manufaktur yang terdaftar di bursa efek Indonesia. Simposium Nasional Akuntansi XV.

Skinner, D. J., \& Sloan, R. G. (2000). Earnings Surprises , Growth Expectations , and Stock Returns or Don't Let an Earnings Torpedo Sink Your Portfolio. University of Michigan Business School, (734).

Werastuti, D. N. S. (2013). Pengaruh Auditor Client Tenure, Debt Default, Reputasi Auditor, Ukuran Klien dan Kondisi Keuangan Terhadap Kualitas. VOKASI Jurnal Riset Akuntansi, 2(1), 99-116.

Whitaker, R. . (1999). The Early Stages of Financial Distress. Journal of Economics and Finance, 123-133.

Wibisono, E. A. (2011). Prediksi Kebangkrutan, Leverage, Audit Sebelumnya Ukuran Perusahaan terhadap Opini Going Concern Perusahaan Manufaktur BEI. Jurnal EMBA, 1(4), 362-373.

Widyantari, A. A. A. P. (2011). Opini Audit Going Concern Dan Faktor-Faktor yang Mempengaruhi. Tesis S2, Univesitas Udayana, Denpasar.

Yati, Y. (2011). Pengaruh Debt Default, Opinion Shopping, Kondisi Keuangan dan Opini Audit Tahun Sebelumnya terhadap Penerimaan Opini Audit Going Concern. Jurnal Akuntansi.

Yuliyani, A. (2017). Pengaruh Financial Distress, Profitabilitas, Leverage, dan Likuiditas Pada Opini Audit Going Concern. Jurnal Akuntansi Universitas Udayana, 19(2), 1490-1520. 